Biogeosciences, 10, 3039-3054, 2013

www.biogeosciences.net/10/3039/2013/

doi:10.5194/bg-10-3039-2013

(C) Author(s) 2013. CC Attribution 3.0 License.

\title{
Seamount physiography and biology in the north-east Atlantic and Mediterranean Sea
}

\author{
T. Morato ${ }^{1}$, K. Ø. Kvile ${ }^{1}$, G. H. Taranto ${ }^{1}$, F. Tempera ${ }^{1}$, B. E. Narayanaswamy ${ }^{2}$, D. Hebbeln ${ }^{3}$, G. M. Menezes ${ }^{1}$, \\ C. Wienberg ${ }^{3}$, R. S. Santos ${ }^{1}$, and T. J. Pitcher ${ }^{1,4}$ \\ ${ }^{1}$ Centre of IMAR of the University of the Azores, Departamento de Oceanografia e Pescas and LARSyS Associated \\ Laboratory, Universidade dos Açores, 9901-382 Horta, Portugal \\ ${ }^{2}$ SAMS, Scottish Association for Marine Science, Scottish Marine Institute, Oban, Argyll, Scotland \\ ${ }^{3}$ MARUM, Center for Marine Environmental Sciences, University of Bremen, Leobener Straße, 28359 Bremen, Germany \\ ${ }^{4}$ Fisheries Centre, University of British Columbia, Vancouver, Canada
}

Correspondence to: T. Morato (telmo@uac.pt)

Received: 23 November 2012 - Published in Biogeosciences Discuss.: 20 December 2012

Revised: 8 March 2013 - Accepted: 8 April 2013 - Published: 6 May 2013

\begin{abstract}
This work aims at characterising the seamount physiography and biology in the OSPAR Convention limits (north-east Atlantic Ocean) and Mediterranean Sea. We first inferred potential abundance, location and morphological characteristics of seamounts, and secondly, summarized the existing biological, geological and oceanographic in situ research, identifying examples of well-studied seamounts. Our study showed that the seamount population in the OSPAR area (north-east Atlantic) and in the Mediterranean Sea is large with around 557 and 101 seamount-like features, respectively. Similarly, seamounts occupy large areas of about $616000 \mathrm{~km}^{2}$ in the OSPAR region and of about $89500 \mathrm{~km}^{2}$ in the Mediterranean Sea. The presence of seamounts in the north-east Atlantic has been known since the late 19th century, but overall knowledge regarding seamount ecology and geology is still relatively poor. Only 37 seamounts in the OSPAR area (3.5\% of all seamounts in the region), 22 in the Mediterranean Sea (9.2\% of all seamounts in the region) and 25 in the north-east Atlantic south of the OSPAR area have in situ information. Seamounts mapped in both areas are in general very heterogeneous, showing diverse geophysical characteristics. These differences will likely affect the biological diversity and production of resident and associated organisms.
\end{abstract}

\section{Introduction}

Seamounts are common underwater features in the world oceans and are traditionally described as isolated elevations greater than $1000 \mathrm{~m}$ in relief above the seafloor (Menard, 1964; International Hydrographic Organization, 2008). However, no ecological rationale seems to support the traditional size limit (Pitcher et al., 2007; Wessel, 2007) and this definition has been extensively modified in the literature to better satisfy the needs of different disciplines (Staudigel et al., 2010). Since small underwater features may also play an important role in deep and high sea ecosystems (e.g. Koslow et al., 2001), we considered features greater than $100 \mathrm{~m}$ in height as small seamounts and defined elevations taller than $1000 \mathrm{~m}$ as large seamounts (sensu Pitcher et al., 2007).

The total number of seamounts at a global scale has been estimated in several studies mainly by running mathematical algorithms on global bathymetry grids inferred from satellite altimetry and acoustic soundings (e.g. Kitchingman and Lai, 2004; Wessel et al., 2010; Kim and Wessel, 2011; Yesson et al., 2011). Currently, these approaches are unable to adequately detect small and deep peaks, and thus the estimates of the global abundance of seamounts still bear large uncertainties. A more accurate approach would be to locate seamounts on bathymetry grids originated by shipboard bathymetric profiles. However, the small area of the ocean floor explored using multibeam bathymetry prevents improved analyses of seamount location, morphology and abundance (Hillier and 
Watts, 2007). Recent estimates of the number of seamounts worldwide range from about 25000 to about 140000 large features and potentially from 125000 to 25 million small seamounts or knolls greater than $100 \mathrm{~m}$ in height (Wessel et al., 2010; Kim and Wessel, 2011; Yesson et al., 2011). Despite this imprecision, such estimates highlight seamounts as one of the most prevalent set of habitats of the seabed, forming one of the largest biomes on earth with about 28.8 million $\mathrm{km}^{2}$ (Etnoyer et al., 2010).

The Oslo-Paris Convention for the Protection of the Marine Environment of the north-east Atlantic (OSPAR; http: //www.ospar.org) is an international legal instrument made of representatives of the governments of 15 Contracting Parties and the European Commission. OSPAR has included seamounts in the list of threatened and/or declining habitats and defined these features as undersea mountains whose summits rise more than $1000 \mathrm{~m}$ above the surrounding seafloor (OSPAR, 2008). The official OSPAR database (consulted in September 2011) included 104 seamounts in the high seas and territorial waters of Norway, Sweden, Faroe Islands, UK, Ireland, France, Spain and Portugal. They are, however, still underestimated since many more seamounts are known in the Mid-Atlantic Ridge or in many exclusive economic zones (EEZs). For example, from the Kitchingman et al. (2007) dataset there may be at least 339 large seamounts in the OSPAR area and about 59 in the Mediterranean Sea. More recently, Kim and Wessel (2011) estimated the number of seamounts greater than $1000 \mathrm{~m}$ in height in the OSPAR area as 132 (850 greater than $500 \mathrm{~m})$, while they consider no seamounts to occur in the Mediterranean Sea. However, these estimates were based on global bathymetry datasets that did not consider the most recent multibeam bathymetry surveys conducted in the region.

Recently, the importance of seamount ecosystems has been recognized by the scientific community, management authorities, industry and conservation initiatives (Stocks et al., 2012). Properties associated with underwater reliefs might affect pelagic and benthic life (e.g. Hubbs, 1959; Samadi et al., 2006; Amorim et al., 2009; Morato et al., 2009, 2010a; Clark et al., 2010), influence global and local circulation (e.g. Vastano et al., 1985; Roden, 1987; White et al., 2007), and enlighten deep earth chemistry and processes (Wessel, 2007; Koppers and Watts, 2010; Staudigel and Clague, 2010; Wessel et al., 2010); all factors that draw marine scientists of diverse backgrounds into seamount research. In particular, recent investigations are trying to reveal how geological, oceanographic, ecological and evolutionary processes interact to shape distinct communities on seamounts by altering nutrient regimes, connectivity among distant populations and deep-sea habitat diversity (Genin et al., 1986; Richer de Forges et al., 1987; Genin, 2004; Samadi et al., 2006; McClain, 2007; O'Hara, 2007; Shank, 2010).

At the same time, the scientific community and international organizations recognized that human threats to seamount ecosystems are growing fast and are impacting some vulnerable marine ecosystems (Pitcher et al., 2010; Taranto et al., 2012; FAO, 2009). Therefore, some actions have been taken to regulate the use of seamount resources (NEAFC, 2011; Santos et al., 2009, 2010; Morato et al., 2010c). Major concerns are related to seamount fishing, especially trawling that physically destroys reef-building organisms (Williams et al., 2010), disturbs the abundant seamount filter feeding communities by sediment re-suspension (Clark et al., 2010), and selectively removes long-lived commercially valuable fish species (Pitcher, 2010) that are extremely vulnerable to heavy fishing (Morato et al., 2006). Besides fisheries, deep-sea mining is an emerging issue in seamount management that may seriously affect seamount ecosystems in the future (Halfar and Fujita, 2007; Hein et al., 2010; He et al., 2011; Van Dover, 2011).

However, not all seamounts share the same set of properties and threats (Rowden et al., 2005; Morato et al., 2010b; Clark et al., 2012; Taranto et al., 2012). Therefore, a clear understanding of spatial patterns of threats, biological diversity, production and geophysical properties is crucial for the success of conservation and management actions (Morato et al., 2010c), and for the understanding of oceanographic, geological and ecological processes associated with seamounts.

This work aims at characterising the seamount physiography and biology in OSPAR area, the north-east Atlantic, and the Mediterranean Sea. We first inferred potential abundance, location and morphological characteristics of seamounts in the OSPAR area and Mediterranean waters applying a detection model on the latest bathymetric information available. Secondly, we summarized the existing biological, geological and oceanographic in situ research, pointing out gaps in seamount investigation, potentially distinctive features and examples of well-studied seamounts. In this way, we hope to achieve a snapshot of the knowledge status of seamount ecosystems in the north-east Atlantic and Mediterranean areas, which may represent basic information on which to build future seamount research and management.

\section{Methods}

\subsection{Seamount abundance and distribution in the OSPAR area (north-east Atlantic) and Mediter- ranean Sea}

The ability to identify large seamounts from bathymetric grids (derived from satellite altimetry or ship-based soundings) is key to any attempt to estimate seamount abundance. This generally implies a two-step seamount isolation process that first highlights topographic local maxima or peaks and then compares the surrounding topography with a set of parametric thresholds to determine whether the peaks represent large seamount-like features ( $>1000 \mathrm{~m} h$; height) displaying an approximately circular or elliptical shape. For this part of the study, we applied a methodology developed 


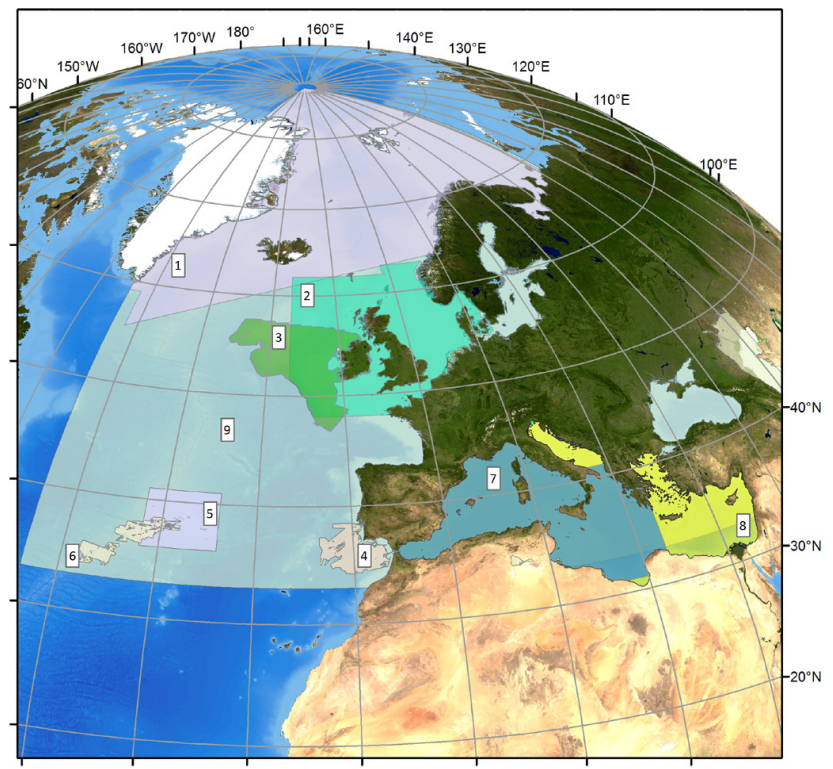

Fig. 1. Outlines of the bathymetry layers used to detect seamounts in the OSPAR area (north-east Atlantic) and the Mediterranean Sea. (1) is the Arctic grid; (2) is the north-east Atlantic grid; (3) is the Ireland grid; (4) is the south-west Iberian margin grid; (5) is the Azores grid; (6) is the Mid-Atlantic Ridge grid; (7) is the Mediterranean 250 grid; (8) is the Mediterranean 800 grid; and (9) is the GEBCO global grid (see Table 1 for details).

by Kitchingman et al. (2007) and adapted by Morato et al. (2008) on several bathymetric grids of different resolutions available for the OSPAR area (north-east Atlantic) and Mediterranean Sea (Fig. 1). After applying the methodology to different bathymetry grids, the outputs originated by each grid were compared. When parts of the bathymetry grids overlapped, the selection of seamounts was undertaken on the layer with the higher resolution. The final list of seamounts in the OSPAR area and Mediterranean Sea was then compiled and resulted from multiple sources. A detailed description of the methodology used is presented in Supplementary Material 1.

\subsection{Seamount characteristics in the OSPAR area (north-east Atlantic) and Mediterranean Sea as re- vealed by in situ studies}

Seamount characteristics in the north-east Atlantic and Mediterranean were determined by mining seamount-related information from the literature and online databases. Some features included in this part of the study may not fall in the commonly used seamount definition (Staudigel et al., 2010). Nevertheless, we decided to include all data available for features that may fall under a more general definition of a seamount (Pitcher et al., 2007) despite their size, shape, location, or tectonic setting. A total of 245 references were consulted for the north-east Atlantic and Mediterranean Sea, in-

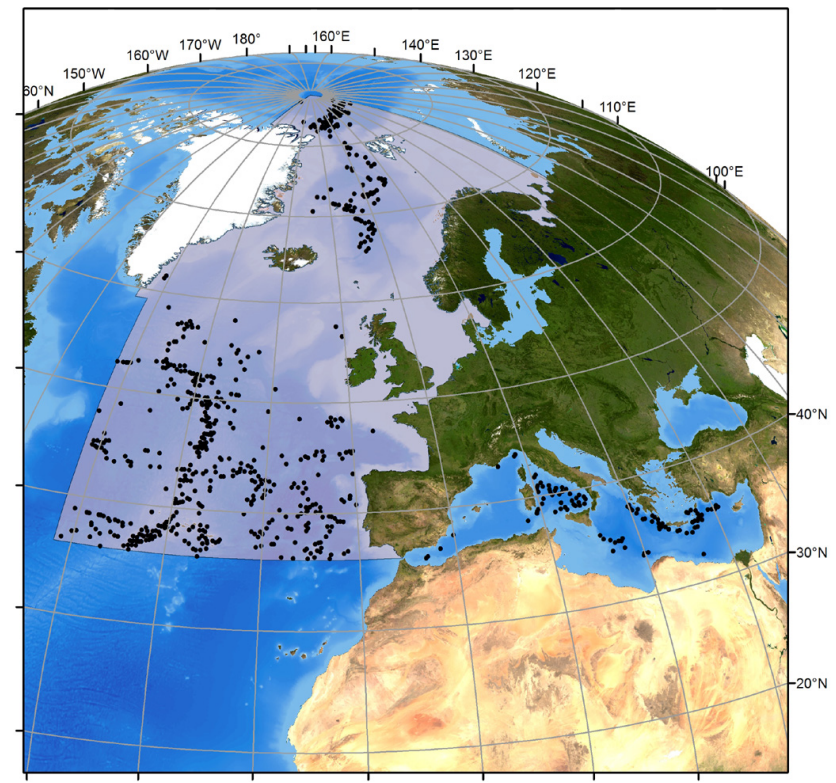

Fig. 2. Final map of the location of potential seamounts (black dots $)$ in the OSPAR area $(n=557)$ and in the Mediterranean Sea ( $n=101)$ as identified using multiple sources of bathymetry grids. Shaded layer shows the limits of the OSPAR area.

cluding scientific publications, reports, online databases, and personal communications (Supplementary Material 2). Two main types of information were recorded from the consulted literature: (1) knowledge scores, used to classify the degree of knowledge of an individual seamount based on a set of key geological, oceanographic and ecological attributes, and (2) actual values, used to describe seamount attributes. The list of attributes used to describe individual seamounts was adapted from Pitcher et al. (2010) and is shown in Supplementary Material 3. In this part of the study, we additionally included information regarding seamounts not strictly belonging to the OSPAR areas but that still belong to the northeast Atlantic. We refer specifically, to the seamounts located around the Canary, Madeira and Cape Verde archipelagos and the Meteor seamount group located off the southern border of the Azores EEZ, where several studies have contributed significantly to our current knowledge of seamounts. Thus, in this part of the study we will refer to seamounts sampled in the north-east Atlantic rather than referring exclusively to seamounts in the OSPAR area. 
Table 1. Number of seamounts identified by the bathymetry grids used in this study.

\begin{tabular}{|c|c|c|}
\hline Area & Number of seamounts & Bathymetry grid \\
\hline Total OSPAR & 557 & Compilation of all datasets \\
\hline North-east Atlantic & 4 & $\begin{array}{l}\text { EMODNET Gridded Bathymetry (EGB). European Marine Observation } \\
\text { and Data Network (EMODNET). The EGB was built at a resolution of } 0.25 \\
\text { arc-minutes using the best available bathymetry from a variety of sources } \\
\text { using a variety of methods (http://www.emodnet-hydrography.eu/content/ } \\
\text { content.asp?menu=0310019_000000). }\end{array}$ \\
\hline Ireland & 6 & $\begin{array}{l}\text { Digital terrain model (DTM) derived from swath bathymetry from the } \\
\text { Geological Survey of Ireland; Interactive Web Data Delivery System at } \\
\text { https://jetstream.gsi.ie/iwdds/index.html. }\end{array}$ \\
\hline South-west Iberian margin & 4 & $\begin{array}{l}\text { Bathymetric dataset compilation funded by the ESF EUROMARGINS } \\
\text { SWIM project. It brings together } 19 \text { multibeam bathymetry surveys exe- } \\
\text { cuted between } 2000 \text { and } 2006 \text { and covering a total area of approximately } \\
180000 \mathrm{~km}^{2} \text {. }\end{array}$ \\
\hline Azores & 42 & $\begin{array}{l}\text { Includes multibeam mapping and global grid data. Available from Lourenço } \\
\text { et al. (1998). }\end{array}$ \\
\hline Mid-Atlantic Ridge & 30 & $\begin{array}{l}\text { MOMAR GIS Database v2 (8 October 2010) with a resolution of } 90 \mathrm{~m} \\
\text { available at http://www.ipgp.fr/rech//gm/MOMAR. }\end{array}$ \\
\hline Arctic & 124 & $\begin{array}{l}\text { IBCAO Grid v. 2.0. Includes the recent years of multibeam mapping. The } \\
\text { resolution of the Polarstereographic grid has been increased from } 2.5 \mathrm{~km} \text { to } \\
2 \mathrm{~km} \text {. The compilation of IBCAO Version } 2.0 \text { is described in Jakobsson et } \\
\text { al. (2008). }\end{array}$ \\
\hline Global & 347 & $\begin{array}{l}\text { GEBCO global dataset. A global } 30 \text { arc-second grid largely gener- } \\
\text { ated by combining quality-controlled ship depth soundings with in- } \\
\text { terpolation between sounding points guided by satellite-derived grav- } \\
\text { ity data. This dataset was only used for areas not covered by any of } \\
\text { the above mentioned databases (http://www.gebco.net/data_and_products/ } \\
\text { gridded_bathymetry_data/). }\end{array}$ \\
\hline Total Mediterranean & 101 & \\
\hline Mediterranean $250 \mathrm{~m}$ & 74 & EMODNET Gridded Bathymetry (see north-east Atlantic). \\
\hline Mediterranean $800 \mathrm{~m}$ & 27 & $\begin{array}{l}\text { GEBCO database. This dataset was only used for areas not covered by the } \\
\text { Mediterranean } 250 \mathrm{~m} \text { database. }\end{array}$ \\
\hline
\end{tabular}

\section{Results and discussion}

\subsection{Seamount abundance and distribution in the OSPAR area (north-east Atlantic) and Mediter- ranean Sea}

A total of 557 potential large seamounts (heights greater than $1000 \mathrm{~m}$ ) were identified in the OSPAR area, while 101 seamount-like features were identified in the Mediterranean Sea (Fig. 2). The accepted outputs of each bathymetric grid are shown in Table 1, while the final list of seamounts generated by our algorithm - including location, depth of the summit and average slope - is provided in Supplementary Material 4. Our method adequately identified topographic structures with heights larger than $1000 \mathrm{~m}$ since the relationship between the cumulative counts of seamounts of different heights show a strong linear relationship (Fig. 3). Nevertheless, the cumulative counts of the features with $1000 \mathrm{~m}$ in height fell below the fitted line, indicating that the numbers for this category are probably somewhat underestimated.
Seamounts in the OSPAR area (north-east Atlantic) are mostly deep (Fig. 4), with a large majority $(n=473 ; 84.9 \%)$ of the summits located between 1000 and $3000 \mathrm{~m}$ depth. Only a small portion $(n=33 ; 5.9 \%)$ of the large seamountlike features in the OSPAR area are shallow, having summits at less than $500 \mathrm{~m}$ depth. The patterns observed in the Mediterranean Sea were different with a greater proportion of seamounts $(n=37 ; 36.6 \%)$ being shallower than $500 \mathrm{~m}$ depth (Fig. 4). Other characteristics of seamounts from the OSPAR area and the Mediterranean Sea were, however, similar. For example, the mean height of the identified seamounts was calculated as $1421 \mathrm{~m}(\mathrm{SD}=403)$ for the OSPAR area and $1493 \mathrm{~m}(\mathrm{SD}=394)$ for the Mediterranean Sea. Predicted seamount height distributions are shown in Fig. 5. Shapes of seamounts, as characterized by the radius of the seamount base $\left(r_{\mathrm{b}}\right)$, the height-radius ratio $\left(\xi_{\mathrm{r}}\right)$ and the average slope $(\varphi)$, did not differ much between both areas. Large seamounts in the OSPAR region were estimated to have a mean basal radius of $r_{\mathrm{b}}=16.1 \mathrm{~km}(\mathrm{SD}=4.3)$, while Mediterranean Sea seamounts showed a mean basal radius 


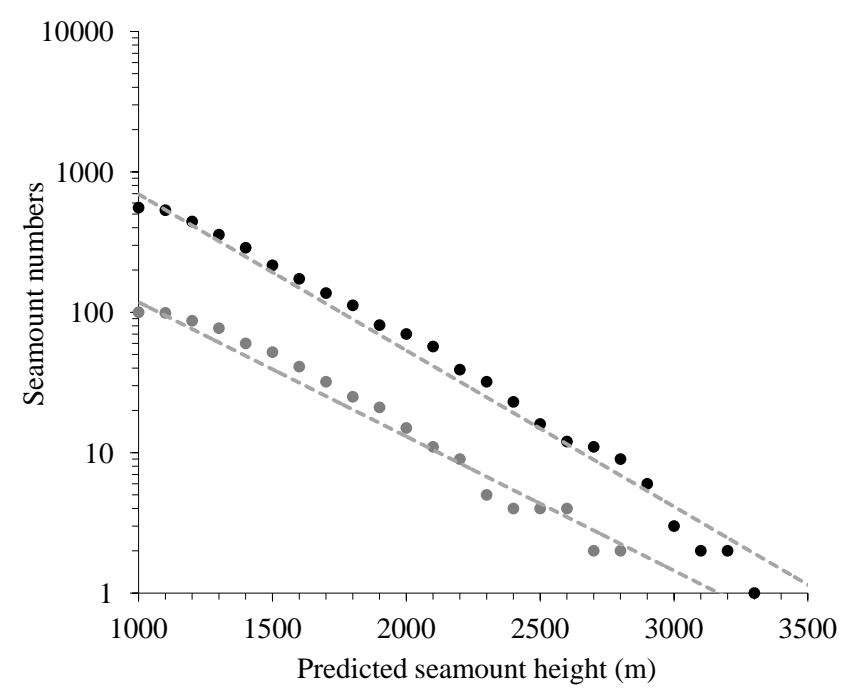

Fig. 3. Cumulative counts of height $(h)$ for identified seamounts. The relationships can be expressed as $v(h)=8977 \cdot e^{-0.003^{H}}$, with $H$ in $\mathrm{km}$ and $r^{2}=0.98$, for the OSPAR area (dark dots) and $v(h)=$ $1067 \cdot e^{-0.002^{H}}$, with $h$ in $\mathrm{km}$ and $r^{2}=0.97$, for the Mediterranean Sea (grey dots).

of $r_{\mathrm{b}}=14.5 \mathrm{~km}(\mathrm{SD}=3.1)$. Accordingly, individual basal areas are similar for OSPAR seamounts $\left(a_{\mathrm{b}}=1105 \mathrm{~km}^{2}\right.$; $\mathrm{SD}=1117)$ and Mediterranean seamounts $\left(a_{\mathrm{b}}=886 \mathrm{~km}^{2}\right.$; $\mathrm{SD}=334)$. Predicted seamount area distributions are shown in Fig. 6. Additional seamount characteristics were also similar for the different regions $\left(\xi_{\mathrm{r}}=0.091 \pm 0.029, \varphi=5.22 \pm\right.$ $1.65^{\circ}$ for OSPAR seamounts and $\xi_{\mathrm{r}}=0.108 \pm 0.039, \varphi=$ $6.173 \pm 2.16^{\circ}$ for Mediterranean Sea seamounts). However, note that most of the features are heterogeneous, as demonstrated, for example, by the slope angles that ranged from $\varphi=0.98^{\circ}$ to $\varphi=15.16^{\circ}$. The relationship between slope angle and summit height for seamounts in the OSPAR area is presented in Fig. 7.

Nevertheless, the application of our methodology to the new bathymetry grids demonstrated that seamounts may be common features in the OSPAR $(n=557$; about 0.04 seamounts per $1000 \mathrm{~km}^{2}$ ) area and in the Mediterranean Sea $\left(n=101\right.$; about 0.04 seamounts per $\left.1000 \mathrm{~km}^{2}\right)$. Our estimates are higher when compared with previously available seamount numbers: $n=104$ (OSPAR official statistics), $n=$ 339 (Kitchingman et al., 2007) and $n=132$ (Kim and Wessel, 2011) for the OSPAR area, and $n=59$ for the Mediterranean Sea. These discrepancies are due to the fact that we used the most recent available bathymetry grids available for the region. However, our results are lower than the number of seamounts estimated by Yesson et al. (2011), who ran a similar methodology on the GEBCO bathymetry grid, and estimated 1288 seamounts greater than $1000 \mathrm{~m}$ in height in the OSPAR area and 180 in the Mediterranean Sea. The differences in the numbers of seamounts estimated by the two methodologies are partially due to the use of different

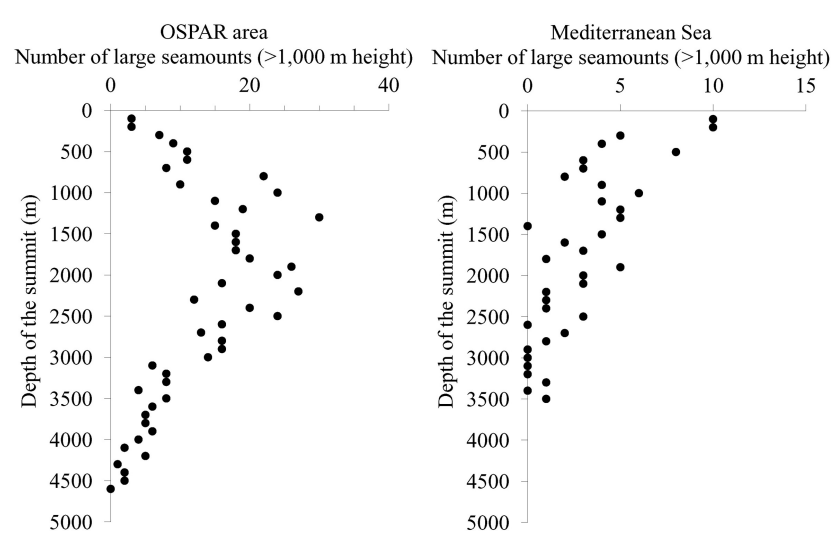

Fig. 4. Depth of the summit frequency distribution of large (height $>1000 \mathrm{~m}$ ) seamount-like features in the OSPAR area (left) and in the Mediterranean Sea (right).

bathymetry datasets and slight differences in the seamount detection algorithm. The Yesson et al. (2011) database is known for overestimating the number of seamounts globally, mainly since it detected small atolls and islands as seamounts or identified multiple peaks in a single seamount as multiples seamounts. In our methodology, we have slightly changed the algorithm in order to reduce the number of false seamounts.

Since our estimates included the bathymetry grids with the highest resolution currently available, they are a step further in the identification of seamounts in the region, and thus more reliable than the datasets previously published. Nonetheless large uncertainties still need to be tackled. The bathymetry grids available for the OSPAR and Mediterranean regions remain partially unresolved and are largely based on satellite altimetry data, with only a small portion resulting from finer ship-borne acoustic surveys. The coarse resolution of such grids results in the blurring of smaller seafloor elevations, which precludes their detection by the algorithms. Hence, our results still have to be considered as an approximate list of OSPAR area and Mediterranean Sea seamounts.

Nevertheless, our estimates draw seamounts as important and relevant areas of the seabed occupying a total area of about $615725 \mathrm{~km}^{2}$ in the OSPAR area and about $89494 \mathrm{~km}^{2}$ in the Mediterranean Sea. Overall, seamounts from these regions showed a wide variety of characteristics with large ranges in size, depth, slope angle and base area. Such diversity in morphological characteristics demonstrates once again that not all seamounts share the same set of properties, making generalisations difficult to formulate.

\subsection{Seamount research in the OSPAR area (north-east Atlantic) and Mediterranean Sea}

From our database, a total of 37 seamounts-like features in the OSPAR area and 22 seamounts in the Mediterranean Sea 

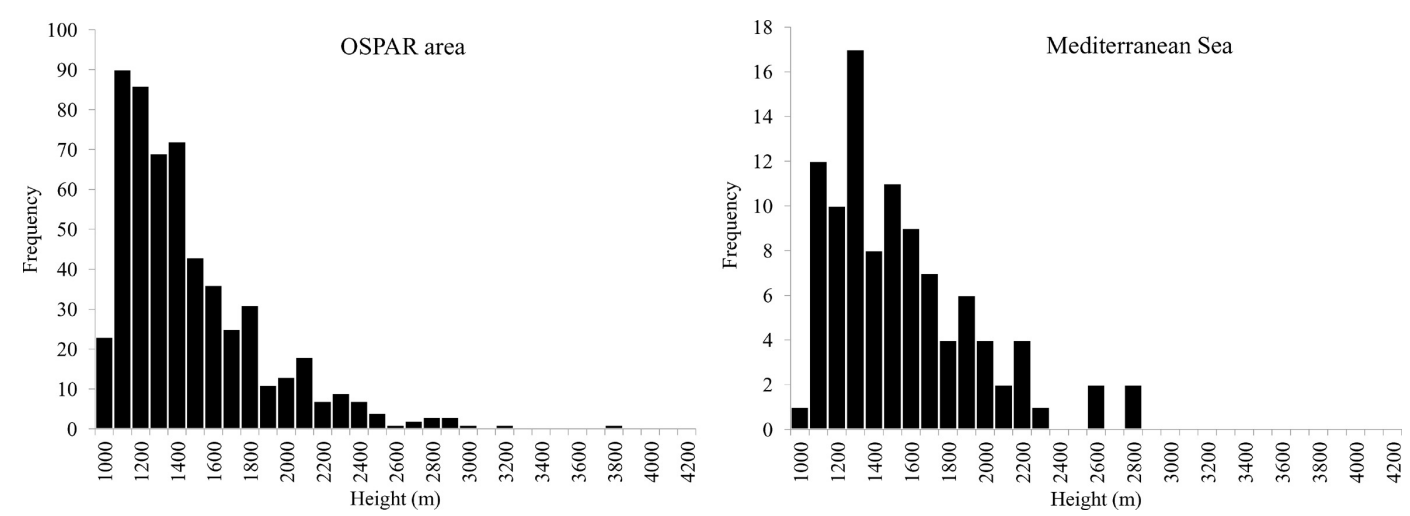

Fig. 5. Histogram of the predicted seamount height $(\mathrm{m})$ distribution of OSPAR (left) and Mediterranean (right) seamount-like features. Bin size is $100 \mathrm{~m}$.
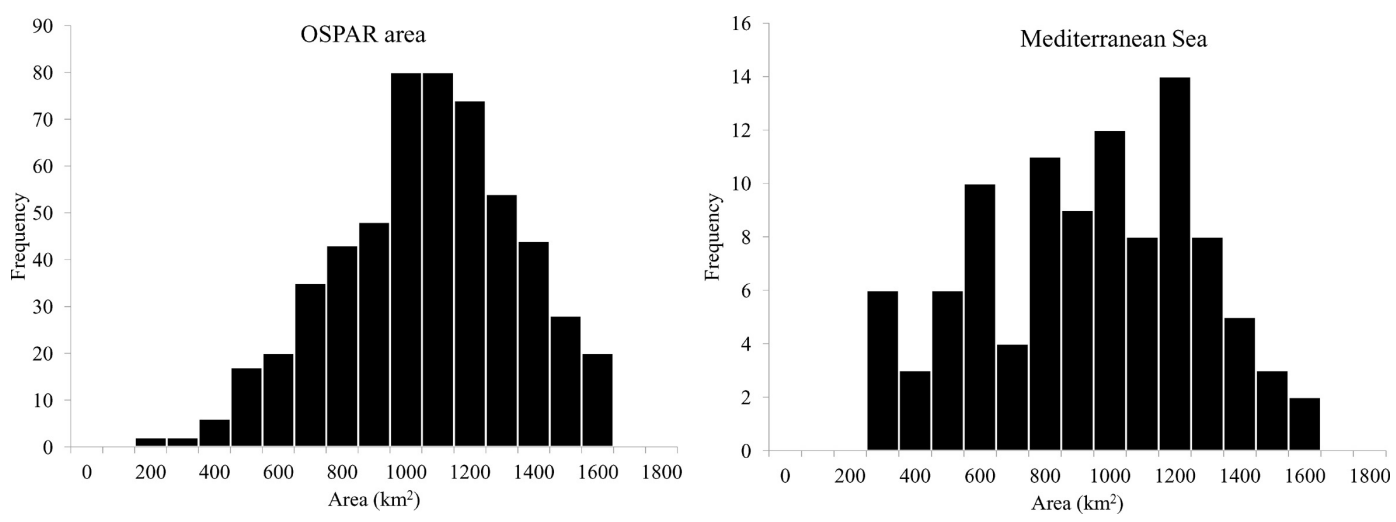

Fig. 6. Histogram of the predicted seamount area $\left(\mathrm{km}^{2}\right)$ distribution of OSPAR (left) and Mediterranean (right) seamount-like features. Bin size is $100 \mathrm{~m}$.

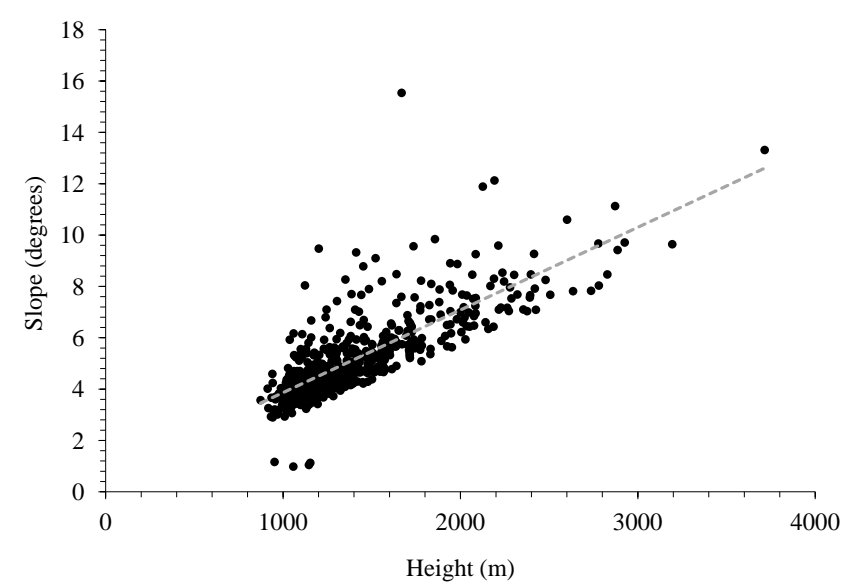

Fig. 7. Relationship between seamounts slope angle $(\varphi)$ and seamount height $(h)$ in the OSPAR area. The relationship can be expressed as $\varphi=0.003 h+0.65 ; r^{2}=0.62$.

(Fig. 8) have been sampled for biological or geological purposes or directly mapped bathymetrically (Supplementary Material 5). Additionally, we included information regard- ing 25 seamounts not strictly belonging to the OSPAR area (see Sect. 2.2). The areas where seamount research has been conducted include the Greenland Basin, the Rockall Trough, the Bay of Biscay, the western Iberian margin, the Azores region, and the Mediterranean Sea's eastern and western basins. Some of these sampled seamounts do not fall under the large seamount-like features (> $1000 \mathrm{~m}$ height) displaying an approximately circular or elliptical shape. Therefore, some of the seamounts shown in Fig. 8 were not mapped in Fig. 2.

In terms of seamount geology, the most commonly known parameters were summit depth, height and age (Fig. 9), both in the north-east Atlantic and the Mediterranean Sea. In general, seamounts studied in the Mediterranean Sea are much younger ( 2 million years in average) than those in the northeast Atlantic (39 million years in average), which may have a direct implication in the biological diversity of seamounts since, for example, age of the seamount may be linked to the presence of endemisms. Additionally, seamounts in the Mediterranean Sea are much less geographically isolated than those in the north-east Atlantic, since the distance to the shelf averaged $61 \mathrm{~km}$ for the Mediterranean Sea and about 


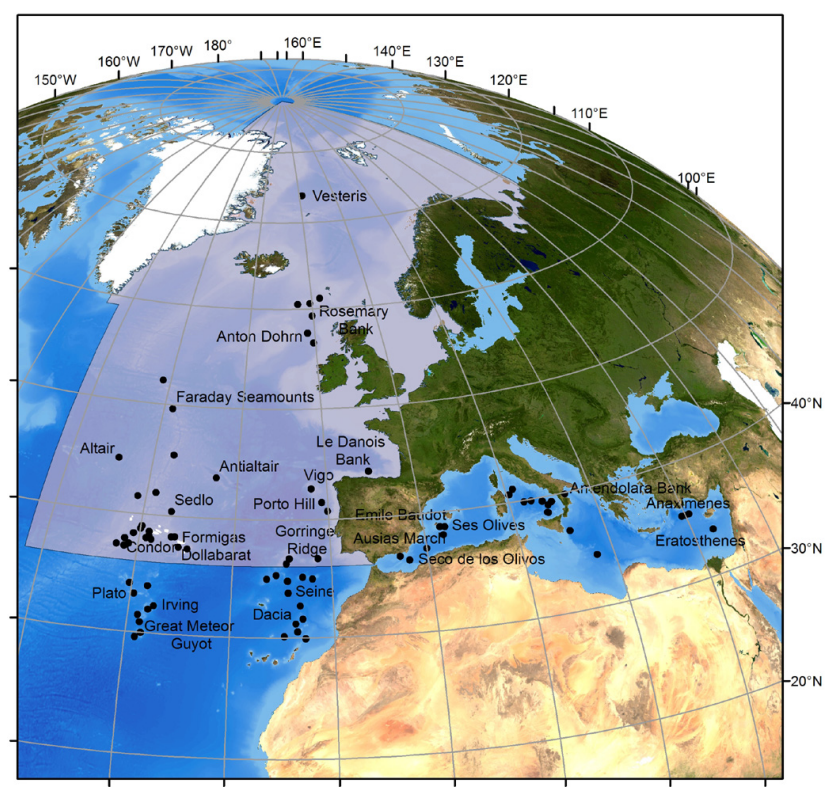

Fig. 8. Locations of seamounts in the north-east Atlantic and Mediterranean Sea that have been sampled for geology, biology or oceanography data (for list of seamounts, see Supplementary Material 5). Shaded layer shows the limits of the OSPAR area.

$1100 \mathrm{~km}$ for the north-east Atlantic. However, the average proximity of a neighbouring seamount ( $79 \mathrm{~km}$ in the Mediterranean Sea and $71 \mathrm{~km}$ in the north-east Atlantic) and average summit depth $(625 \mathrm{~m}$ in the Mediterranean Sea and $560 \mathrm{~m}$ in the north-east Atlantic) did not show major differences between the two areas. The average slope of the studied seamounts was higher for seamounts in the Mediterranean Sea $\left(\varphi=20^{\circ}\right)$ than in the north-east Atlantic $\left(\varphi=13^{\circ}\right)$. Differences in these characteristics will most likely influence the biological communities of these seamounts and will likely affect their average productivity.

The 84 explored seamounts comprise mostly large features, with an average height of over $1800 \mathrm{~m}$. The Great Meteor guyot is the largest known seamount and reaches $5425 \mathrm{~m}$ above the sea bottom, being higher than any mountain in Western Europe (see Sect. 3.3.6). For comparison, Mount Blanc, the highest peak in the Alps, is "only" $4810 \mathrm{~m}$. The depths of the seamount summits range from a few meters (João Valente Bank, Cape Verde; Monteiro et al., 2008) to $2554 \mathrm{~m}$ (Alfeo Seamount, Ionian Sea; Ben-Avraham et al., 1983), showing an average depth of about $600 \mathrm{~m}$. Most seamounts are of volcanic origin, but interestingly hydrothermal activity has only been reported on 9 seamounts ( $11 \%$ of studied seamounts). Of these, the Azorean João de Castro Bank has been explored in detail, with reports of a unique ecosystem of protists and bacteria potentially adapted to metal rich waters (Colaço et al., 2006).

Most of the detailed information available regarding seamount ecology in the north-east Atlantic and Mediter- ranean Sea (Fig. 9) is related to benthic invertebrates (information available for $56 \%$ of the sampled seamounts), demersal (51\% of the sampled seamounts) and deep-water fish ( $42 \%$ of the sampled seamounts) and deep-water corals (49\% of the sampled seamounts). Demersal invertebrates have been sampled on 36 of the seamounts in the north-east Atlantic and 12 in the Mediterranean Sea. Corals (cnidarians of the class Anthozoa, excluding the sea anemones in the orders Actiniaria and Ceriantharia) have been reported on 33 and 11 seamounts in the north-east Atlantic and Mediterranean Sea, respectively. Seamount fish communities have been studied in about 34 seamounts in the north-east Atlantic and about 9 in the Mediterranean Sea. Research on seamount fish communities has been conducted in various locations within the OSPAR area, in particular around the Azorean and Meteor seamounts and along the Iberian margin (e.g. Menezes et al., 2006, 2009; Pakhorukov, 2008). Depending on the depth of the seamount, the dominant species are typical deep-sea fish (bathydemersal or bathypelagic) or more shallow species (demersal or benthopelagic).

Stony corals (order Scleractinia) are the most common deep-sea corals (reported on 27 of the abovementioned seamounts), but gorgonians and black corals (order Antipatharia) have also been found on many seamounts. Other intensely studied taxa comprised arthropods, mainly decapod crustaceans, but also other crustaceans and sea spiders (class Pycnogonida), molluses, both gastropods and bivalves, and echinoderms, in particular sea urchins (Class Echinoidea). Taxa such as sponges, annelids and bryozoans have also been sampled from many of the seamounts.

Prince Albert I of Monaco was one of the pioneers of marine science in general, and seamount research in particular. Between 1885 and 1911 he commanded 13 campaigns in the Azores area of the north-east Atlantic, producing new bathymetric charts and identifying the major topographical features, including the Princess Alice seamounts in 1896 (Porteiro, 2009). The diversity and abundance of species found in the area was remarkable (Carpine-Lancre and Saldanha, 1992). Although the presence of seamounts in the north-east Atlantic has been known since the late 19th century (Buchanan, 1886), little information on their ecology was published until the 1970s, when German scientists led the way with the Great Meteor expeditions (e.g. Hesthagen, 1970).

Ever since, other seamounts such as the Josephine and the Great Meteor Seamount complex have been subject to immense ecological research (see Sect. 3.3.6). Contrastingly, many other features have been bathymetrically mapped but to our knowledge received no ecological research (e.g. the Vigo and Porto seamounts, Mougenot et al., 1984). Since the transition into the 21 st century, a boost occurred in the number of studies regarding seamount ecology. Biological studies have continued in the Azorean and Great Meteor seamounts, with a focus on fisheries, plankton and benthic biotope zonation studies (e.g. Rogers, 1994; Uiblein et al., 


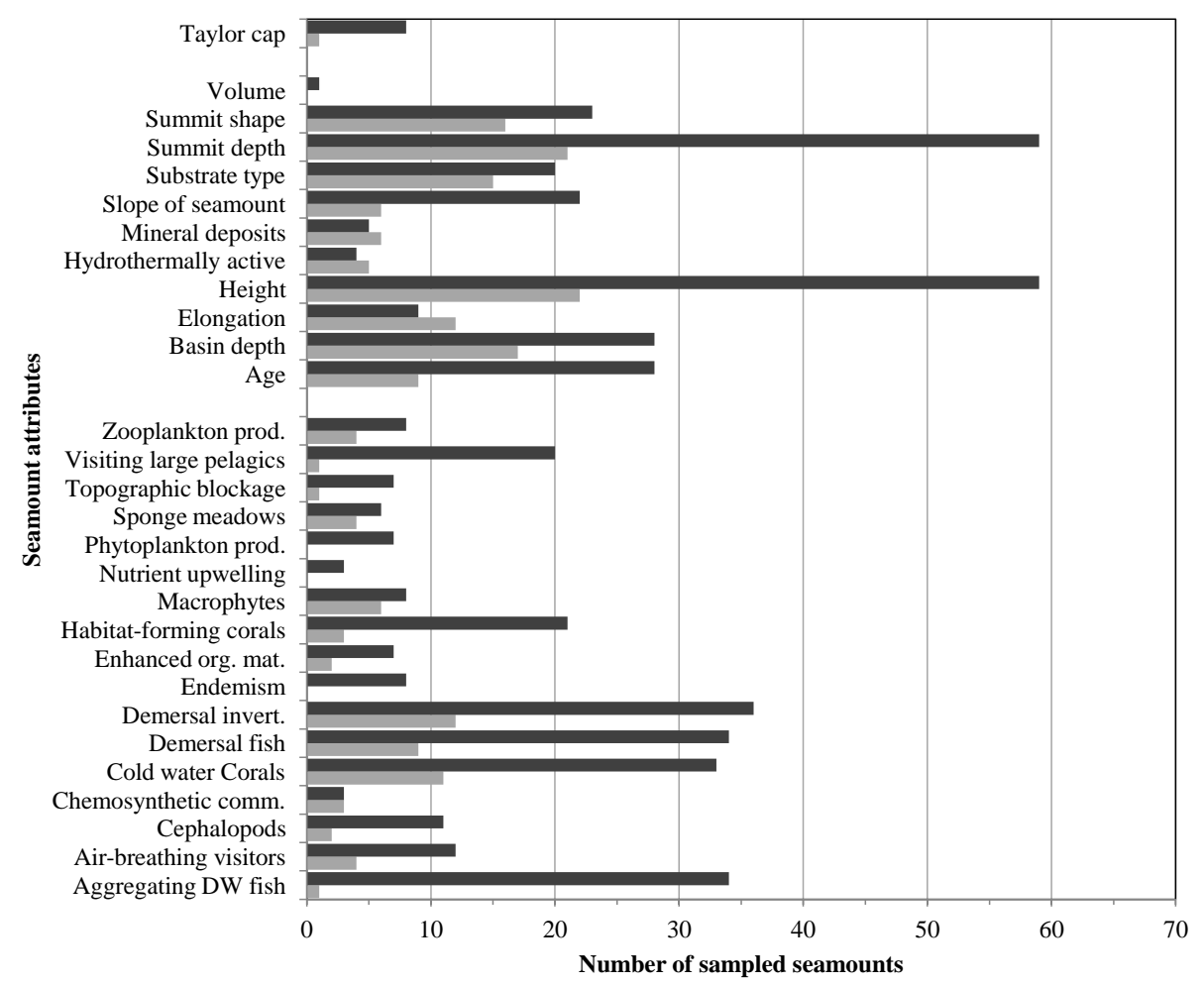

Fig. 9. Number of seamounts sampled for different attributes in the north-east Atlantic (dark grey) and in the Mediterranean Sea (grey).

1999; Fock et al., 2002; Martin and Nellen, 2004; Nellen and Ruseler, 2004; Tempera et al., 2012). The OASIS project (Christiansen and Wolff, 2009) has shed further light on both oceanographic and ecological aspects of two north-east Atlantic seamounts (Seine and Sedlo) and demonstrated the importance of multidisciplinary studies. This multidisciplinary approach of the seamount research was recently extended to Condor Seamount (see Sect. 3.3.3), which was temporary closed to fishing for longer-term research purposes (Morato et al., 2010c; Giacomello and Menezes, 2011).

In the Mediterranean Sea, seamount research has traditionally been focused on geology with many western Mediterranean seamounts being bathymetrically well mapped. In particular, seamounts in the Tyrrhenian Sea are relatively well studied in terms of volcanology and mineralogy (e.g. Trua et al., 2002; Dekov and Savelli, 2004). Compared to geological exploration, early ecological research in the Mediterranean Sea has been sparse: only a few publications are available from the last century (e.g. Perrone, 1982; Strusi et al., 1985; Galil and Zibrowius, 1998). However, recent studies regarding seamount ecology reflect a growing interest for this field in the Mediterranean (e.g. Freiwald et al., 2009; Ettoumi et al., 2010; Bo et al., 2011, 2012; Sevastou et al., 2011; Shank et al., 2011). In the Cape Verde and the eastern Mediterranean regions, excluding a few features, seamount ecosystems remain largely unknown.
Conservation organizations have recently been engaged in seamount research in both the north-east Atlantic and Mediterranean, which has augmented considerably the knowledge of some features in terms of habitat and species diversity (OCEANA, 2008, 2010). These findings promoted the creation of the first seamount marine protected area in the Mediterranean Sea (see Sect. 3.3.7).

\subsection{Seamount characteristics in the OSPAR area (north-east Atlantic) and Mediterranean Sea as re- vealed by in situ studies}

Some examples of well-studied seamounts in the north-east Atlantic and Mediterranean Sea are presented here. This is not an exhaustive list of all studied seamounts in the region but intends to compile a diverse list of features throughout the area.

\subsubsection{Vesterisbanken $\left(73.52^{\circ} \mathrm{N}, \mathbf{9 . 1 3}^{\circ} \mathrm{W}\right)$}

The Vesterisbanken Seamount in the Greenland Basin is the northernmost seamount in the OSPAR area for which detailed information is available. This large, isolated feature was visited by researchers during the 1980s and early 1990s. Detailed studies describe the substrate composition and bathymetry of this seamount, which is a nearly $3000 \mathrm{~m}$ high feature with two peaks (Hempel et al., 1991; Cherkis et al., 1994). With an almost year-round ice-cover, it is 
not straightforward to conduct biological investigations in the Arctic. However, one expedition in 1990 (Henrich et al., 1995) provided a thorough description of the different benthic invertebrate communities inhabiting this seamount, from the top of the summit to the deepest flanks. Bioherms constructed by sponges, bryozoans and serpulid polychaetes cover large proportions of the seamount summit and flanks, with depth-wise changes in species composition. Patches of sandy or muddy substrate within these mats, as well as occasional rocky outcrops, create a range of different habitats. In addition, starfish, brittle stars, octocorals, hydrozoans and bivalves inhabit this seamount. The Vesterisbanken fauna is likely highly dependent on the rapid input of energy from upper waters during the short Arctic summer.

\subsubsection{Anton Dohrn $\left(57.45^{\circ} \mathrm{N}, \mathbf{1 1 . 1}^{\circ} \mathrm{W}\right)$ and Rosemary Bank seamounts $\left(59.25^{\circ} \mathrm{N}, \mathbf{1 0 . 1 5}^{\circ} \mathrm{W}\right)$}

The Anton Dohrn and Rosemary Bank seamounts are located in the Rockall Trough, north-east Atlantic, about $120 \mathrm{~km}$ north-west of the UK mainland and located in the UK's EEZ. Anton Dohrn is a classically circular-shaped seamount with steep flanks that lead to a relatively flat and completely sediment-covered summit ( $\sim 40 \mathrm{~km}$ in diameter) (Jacobs, 2006). The flanks are devoid of canyons and gullies. Instead, there are a few hills/parasitic cones on the eastern and northwestern sides. Rosemary Bank is a more elongate domeshaped seamount $(\sim 70 \mathrm{~km}$ in diameter). Recent work undertaken on Rosemary Bank has found a number of small parasitic cones (Jacobs, 2006) as well as slide scars and slopes that are terraced (Howe et al., 2006). Both seamounts belong to an area commonly termed the "cradle of deep-sea biology" (Gage, 2001), as the deep-waters of the north-east Atlantic were sampled by Victorian scientists. However, the seamount and banks were rarely sampled in those days because of the difficulties associated with sampling steep topography. Anton Dohrn has been, however, the focus of deep-water fishing and numerous trawl-marks were observed on side-scan sonar imagery (Jacobs, 2006).

Anton Dohrn and Rosemary Bank seamounts were sampled in detail in 2005 and 2006 (Narayanaswamy et al., 2006; Howell et al., 2007), with additional sampling taking place in 2009 (Stewart et al., 2009). The summit of Anton Dohrn was found to be covered by a large number of brachiopod valves and barnacle plates interrupted by large areas of sandy/gravel substrate supporting encrusting serpulids and sponges. In addition, cold scleractinian deep-water corals (e.g. Lophelia pertusa) were observed supporting large assemblages of sponges, gorgonians, cup corals (Caryophyllia spp.), and other fauna on the summit edge (JNCC, 2011). Echinoids were the dominant mobile fauna with noticeable changes in species dominance with increasing depths (Narayanaswamy et al., 2006). Anton Dohrn has recently been proposed as a Special Area of Conservation (JNCC, 2011). On the summit of Rosemary Bank, fauna such as cup corals, sessile ho- luthurians and anemones were present at the edge of the iceberg plough marks, whilst on the terraced slopes a high diversity of fauna was found including stony corals, gorgonians, sponges and anemones. Ophiuroids were the dominant epifauna found at the base of Rosemary Bank (Howell et al., 2010a, b).

\subsubsection{Condor Seamount $\left(38.55^{\circ} \mathrm{N}, \mathbf{2 9 . 0 4}^{\circ} \mathrm{W}\right)$}

Condor Seamount is located about $17 \mathrm{~km}$ to the south-west of Faial Island (Azores), is about $26 \mathrm{~km}$ in length and $7.4 \mathrm{~km}$ wide at the $1000 \mathrm{~m}$ depth contour, with depths ranging from 180 to more than $1000 \mathrm{~m}$, and an estimated planar area of $432 \mathrm{~km}^{2}$ (Tempera et al., 2012). The main geomorphologic characteristics of the seamounts were further described by Tempera et al. (2012). The seamount is under a temporary fishing moratorium, established in 2010 , allowing the installation of a scientific observatory to improve the understanding of seamount ecological structure and functioning (Morato et al., 2010c). This moratorium will last until 2014, when its future will be discussed with the stakeholders.

Condor Seamount hosts a peculiar multiscale dynamic of oceanographic conditions, including enhanced mixing, upwelling-downwelling processes and closed circulation structures over the seamount, that make it distinct from the surrounding ocean (Bashmachnikov et al., 2011). It hosts habitats of conservational importance, constituted of deepwater coral gardens and deep-sea sponge aggregations (Tempera et al., 2012; Braga-Henriques et al., 2011). The Condor Seamount food chain is composed of five trophic levels with mesopelagic organisms being the link between the epipelagic realm and the benthic and benthopelagic organisms. Predation of epipelagic organisms by mesopelagic organisms and the trapping of the latter above the seamount, in addition to lateral advection, increase the carbon supply to the Condor Seamount (Colaço et al., 2011). Preliminary results of the study of sediment microbial assemblages revealed a general low availability of food for benthic consumers at the Condor summit (Bongiorni, 2011).

Condor Seamount has been an important fishing ground for bottom longline and handline fishing (Giacomello and Menezes, 2011). The fact that bottom trawling was never employed may help explain why the seamount still hosts benthic communities in a relatively good state (Tempera et al., 2012). Research activities, big-game fishing, recreational fishing, whale watching and scuba-diving activities are also important ancillary activities in the Condor Seamount, but to a lesser extent (Giacomello and Menezes, 2011). Intense handline and longline fisheries have, however, caused important reductions in the abundance of many demersal fish species. Species life history characteristics, their degree of residency on the Condor Seamount, and their dependence from outside source areas appear to be important determinants for the status of the fish species and the timescales required for recoveries to earlier abundances (Menezes et al., 2011). 


\subsubsection{Coral Patch Seamount $\left(34.93^{\circ} \mathrm{N}, \mathrm{11.95}^{\circ} \mathrm{W}\right)$}

Coral Patch is a still largely unexplored seamount, located roughly half-way between Seine Seamount and Portugal. Coral Patch is a sub-elliptical WSW-ENE elongated seamount, about $120 \mathrm{~km}$ long and $70 \mathrm{~km}$ wide (D'Oriano et al., 2010) with its south-western top reaching a water depth of about $560 \mathrm{~m}$ (Wienberg et al., 2012). Seismic and bathymetric data show that Coral Patch is a composite structure with nine distinct coalescent volcanic cones developed on its top (D'Oriano et al., 2010) that are emplaced on a preexisting sedimentary structural high (Zitellini et al., 2009).

The south-western top of Coral Patch Seamount is dominated by exposed hard substrate, whereas soft sediment is just a minor substrate component (Wienberg et al., 2012). Although exposed hardgrounds are dominant, and thus, offer suitable habitat for settlement by benthic organisms, the megafauna shows rather scarce occurrence except for cidarid echinoids and crinoids which were frequently observed. Overall, the megafauna on Coral Patch Seamount comprises benthic to epibenthic living organisms with a clear dominance of suspension-feeders, which were observed as live occurrences as well as their skeletal remnants (e.g. shell hash, coral debris). Scleractinian deep-water corals, from which the seamount derived its name, are rare and just comprise isolated small-sized $(<20 \mathrm{~cm}$ in diameter) live occurrences of the species Lophelia pertusa and Madrepora oculata. In contrast, dead coral framework and coral rubble are more frequent, pointing to a higher abundance of corals on Coral Patch during the recent past (Wienberg et al., 2012). Dead but relatively fresh-looking coral framework was often observed to be entangled in lost longlines. Overall, longlines and various species of commercially important fish were frequently observed, emphasising the potential of Coral Patch Seamount as an important target for fisheries that may have impacted the entire benthic community (Wienberg et al., 2012).

\subsubsection{Seine Seamount $\left(3^{3.76}{ }^{\circ} \mathrm{N}, \mathbf{1 4 . 3 8}^{\circ} \mathrm{W}\right)$}

A seamount for which our knowledge has increased rapidly over the last few years is the Seine Seamount, situated near the Madeira Islands. Virtually nothing was known about this seamount until the initiation of the OASIS (OceAnic Seamounts: an Integrated Study) project in 2002 (Christiansen and Wolff, 2009). This scientific initiative assessed oceanographic, geochemical and biological aspects of the Seine Seamount (north-eastern of Madeira Island), which was visited in total seven times over a three-year period. The substrate of the Seine Seamount is a mix of soft sediment and hard rock, providing habitat both for sessile megabenthos such as sponges and corals as well as burrowing infauna (Bett et al., 2004). A total of 11 different invertebrate phyla have been identified for the seamount. In addition, important studies were made of the demersal and benthopelagic fish community, with about 50 different species having been observed (Christiansen et al., 2009; Menezes et al., 2009). According to Menezes et al. (2009), higher fish abundances were observed at Seine Seamount compared to adjacent island slopes of similar depths. However, it is difficult to distinguish if such differences were related to "seamount effects" or to different fishing pressures. A study conducted by Christiansen et al. (2009) found no significant differences in fish abundance at Seine Seamount.

The OASIS project did not find any evidence for constant high productivity at the two seamounts studied (Arístegui et al., 2009; Martin and Christiansen, 2009), but a "seamount effect" was observed on the microbial community structure and biomass (Mendonça et al., 2012). Vilas et al. (2009) further suggested that the seamount created an effect on the fluxes of organic matter, with a higher concentration of particulate organic matter above the Seine summit than at other similar depths. This might constitute an important food source for the benthic community, but further studies need to be done to confirm this.

\subsubsection{Great Meteor guyot $\left(30.00^{\circ} \mathrm{N}, 28.50^{\circ} \mathrm{W}\right)$}

The Great Meteor Seamount, situated south of the Azores, is one of the largest known seamounts in the north-east Atlantic, rising from about $4500 \mathrm{~m}$ depth to $270 \mathrm{~m}$ below the sea surface. It is also the most thoroughly studied seamount in the north-east Atlantic. Its history of research is dominated by biological sampling, though some geological investigations were conducted in the 1960s and 1970s (e.g. Watts et al., 1975; Wendt et al., 1976; von Stackelberg et al., 1979).

The majority of the cruises that have visited the Great Meteor sampled the demersal invertebrate fauna. A total of 16 references have been incorporated in the Seamount Ecosystem Evaluation Framework (Pitcher et al., 2010) regarding this attribute. Most studies are qualitative, and often focus on specific taxonomic groups, such as copepods or gastropods (George and Schminke, 2002; Gofas, 2007). Nevertheless, some quantitative studies have been conducted, comparing both abundances and diversity of invertebrate megafauna with the adjacent continental slope and neighbouring seamounts (Piepenburg and Müller, 2002; Bartsch, 2008). Perhaps surprisingly, these studies found the invertebrate fauna on the Great Meteor guyot to be relatively poor, both in terms of abundances and species diversity.

The Great Meteor is among the few seamounts in the north-east Atlantic where ecosystem dynamics have been addressed. Several studies have indicated the trapping of vertically migrating organisms above the seamount summit, which might provide a resource for the demersal community (e.g. Fock et al., 2002; Nellen and Ruseler, 2004; SchnackSchiel and Henning, 2004). There were also observations of a Taylor column that might retain larvae, plankton or nutrients around the seamount (Beckmann and Mohn, 2002). However, the levels of primary and secondary (zooplankton) 
production above the seamount seem not to be significantly different from that of the surrounding open ocean, though temporary variation exists (Martin and Nellen, 2004; Mouriño et al., 2000). Low local productivity might explain why the demersal fauna of this seamount is relatively poor. Fish species from the Great Meteor Seamount showed strong affinities with the African coast, Madeira, and the Canary Islands (Uiblein et al., 1999).

\subsubsection{Ses Olives $\left(36.52^{\circ} \mathrm{N}, \mathbf{2 . 8 5}^{\circ} \mathrm{W}\right)$, Ausiàs March $\left(38.73^{\circ} \mathrm{N}, 1.80^{\circ} \mathrm{E}\right)$, and Emile Baudot $\left(38.70^{\circ} \mathrm{N}\right.$, $\left.2.33^{\circ} \mathrm{E}\right)$ seamounts}

Three seamounts in the Channel of Mallorca have recently received the attention of conservationists working to preserve the biodiversity of the Mediterranean Sea. Acosta et al. $(2003,2004)$ have described the geomorphology of these features, called Ses Olives, Mont Ausiàs March and Emile Baudot. Compared to Atlantic seamounts, these Mediterranean features are located in relatively shallow water (300$650 \mathrm{~m}$ depth). Ses Olives and Mont Ausiàs March are both flat-topped and probably of continental origin, while the more south-easterly located Emile Baudot is surrounded by a large number of pinnacles, and might be of volcanic origin. The summit of Ses Olives reaches $300 \mathrm{~m}$ depth, while Emile Baudot and Ausiàs March are shallower seamounts, with depths of $150 \mathrm{~m}$ and $125 \mathrm{~m}$, respectively.

The seamounts in the Mallorca Channel had not been biologically researched until the sampling carried out by the conservation organization OCEANA in 2007 (OCEANA, 2008). During intense sampling around 200 different taxa were observed. Emile Baudot and Ausiàs March both reach within the photic zone, allowing the development of encrusting red algae, which were often covered by sponges. Deepsea corals, sea anemones and echinoderms were also frequently observed. The summit of the deeper Ses Olives is largely covered by sandy sediment and inhabited by crustaceans and molluscs. A large number of demersal fish species were also reported, among which many are of commercial interest. Emilie Baudot has been a much used fishing ground, and at Ausiàs March damage from bottom trawling has been observed. Based on the work by OCEANA, these three seamounts along with the Bell Guyot were recently designated marine protected areas by the Spanish government (Madina, 2011).

\subsubsection{Eratosthenes Seamount $\left(33.67^{\circ} \mathrm{N}, 3^{32.67^{\circ}} \mathrm{E}\right)$}

The Eratosthenes Seamount, located in the eastern Mediterranean Sea, was first described from geological surveys that used bathymetric, seismic and magnetic data to define the regional topography (e.g. Ben-Avraham et al., 1983; Tanner and Williams, 1984). Early descriptions of hydrothermal manganese deposits from the seamount suggested recent hydrothermal activity (Varnavas et al., 1988). Later, a drilling program provided details about both substrate composition and the geological history of the Eratosthenes, a platform built up mainly by limestone on continental crust (Robertson, 1998). There was only one biological investigation on this seamount during the last century, but the samples were described as "surprisingly diverse" for the region (Galil and Zibrowius, 1998). Various epifaunal taxa were found attached to the hard substrate of the seamount, including stony corals and sponges. The Eratosthenes Seamount has recently been revisited by scientists investigating meiofaunal and macrofaunal diversity, a nearly untouched area of seamount research. The preliminary results of this study indicated relatively high meiofaunal diversity with a decrease in abundance and diversity with increasing depth (Sevastou et al., 2011). However, macrofaunal abundance and diversity were relatively low (Narayanaswamy, 2012). Recent video surveys on the flanks of the Eratosthenes Seamount revealed vent-like communities around shimmering water of increased ambient temperature, indicating present hydrothermal activity on this seamount (Mayer et al., 2011).

\section{Conclusions}

Our study revealed that the seamount population in the OSPAR area and in the Mediterranean Sea is large with around 557 seamount-like features in the whole OSPAR area and about 101 in the Mediterranean Sea. These values were higher than previous estimates since we used the latest bathymetry grids available for the region. Similarly, these topographic features occupy a large area of about $616000 \mathrm{~km}^{2}$ in the OSPAR area. In the Mediterranean Sea, seamounts occupy an estimated area of about $89500 \mathrm{~km}^{2}$, much larger than previously thought. The 84 seamounts in the north-east Atlantic and Mediterranean from which we have found in situ information are in general large features that reach shallow depths but exhibit different ages and slopes. Moreover, seamounts mapped in the area are in general very heterogeneous, showing diverse geophysical characteristics. These differences will likely affect the biological diversity and production of resident and associated organisms.

\section{Supplementary material related to this article is available online at: http://www.biogeosciences.net/10/ 3039/2013/bg-10-3039-2013-supplement.zip.}

Acknowledgements. This research has received funding from the European Community 7th Framework Programme (FP7/20072013) under the CoralFISH project, grant agreement no. 213144, and HERMIONE project, grant agreement no. 226354. IMARDOP/UAç (research and development unit \#531) and LARSyS Associated Laboratory are supported by FCT (under the strategic 
projects OE, COMPETE, QREN) and by DRCTC - Regional Government of the Azores through a pluriannual funding scheme. Additional funding was received from the Marine Conservation Institute through the Mia J. Tegner Memorial Research Grant Program in Marine Environmental History and Historical Marine Ecology, and FCT Pest/OE/EEI/LA00009/2011. TM was funded by POPH, QREN European Social Fund and the Portuguese Ministry for Science and Education. FT was funded by a post-doc grant (SFRH/BPD/79801/2011) from the Portuguese Foundation for Science and Technology (FCT) and by project MeshAtlantic (Atlantic Area 2009-1/110). TJP was funded in part by the Natural Science and Engineering Research Council of Canada. BN was funded by the Natural Environmental Research Council TOPODEEP project (NE/G006415/1). We would like to acknowledge the collaboration of Ricardo Medeiros and many other colleagues that have shared information, publications or ideas with us.

The service charges for this open access publication have been covered by the EC FP7 CoralFISH project, grant agreement no. 213144.

Edited by: R. Danovaro

\section{References}

Acosta, J., Canals, M., López-Martinez, J., Munõz, A., Herranz, P., Urgeles, R., Palomo, C., and Casamor, J. L.: The Balearic Promontory geomorphology (western Mediterranean): morphostructure and active processes, Geomorphology, 49, 177204, 2003.

Acosta, J., Ancochea, E., Canals, M., Huertas, M. J., and Uchupi, E.: Early Pleistocene volcanism in the Emile Baudot Seamount, Balearic Promontory (western Mediterranean Sea), Mar. Geol., 207, 247-257, 2004.

Amorim, P., Figueiredo, M., Machete, M., Morato, T., Martins, A., and Santos, R. S.: Spatial variability of seabird distribution associated with environmental factors: a case study of marine Important Bird Areas in the Azores, ICES J. Mar. Sci., 66, 29-40, 2009.

Arístegui, J., Mendonça, A., Vilas, J. C., Espino, M., Polo, I., Montero, M. F., and Martins, A.: Plankton metabolic balance at two North Atlantic seamounts, Deep-Sea Res. Pt. II, 56, 2646-2655, 2009.

Bartsch, I.: Notes on ophiuroids from the Great Meteor Seamount (Northeastern Atlantic) (Echinodermata, Ophiuroidea), Spixiana, 31, 233-239, 2008.

Bashmachnikov, I., Mendonça, A., Sequeira, S., Gomes, S., Medeiros, A., Loureiro, C., and Martins, A.: Physical Oceanography, in CONDOR Observatory for long-term study and monitoring of Azorean seamount ecosystems, Final Project Report, Arquivos do DOP, Série Estudos 1/2012, Horta, Portugal, 39-45, 2011.

Beckmann, A. and Mohn, C.: The upper ocean circulation at Great Meteor Seamount. Part II: Retention potential of the seamountinduced circulation, Ocean Dynam., 52, 194-204, 2002.

Ben-Avraham, Z., Harrison, C. G. A., Klein, E., and Shoham, Y.: Seamont magnetism in the Ionian Sea, eastern Mediterranean, Mar. Geophys. Res., 5, 389-404, 1983.
Bett, B. J., Watson, S. A., Gooday, A. J., and Billett, D. S. M.: Ecology of seamount megabenthos: Seine and Sedlo Seamounts (NE Atlantic), Data report for the National Oceanography Centre, DEEPSEAS Group. Southampton, UK, 2004.

Bo, M., Bertolino, M., Borghini, M., Castellano, M., Covazzi Harriague, A., Di Camillo, C. G., Gasparini, G., Misic, C., Povero, P., Pusceddu, A., Schroeder, K., and Bavestrello, G.: Characteristics of the Mesophotic Megabenthic Assemblages of the Vercelli Seamount (North Tyrrhenian Sea), PLoS ONE, 6, e16357, doi:10.1371/journal.pone.0016357, 2011.

Bo, M., Bertolino, M., Bavestrello, G., Canese, S., Giusti, M., Angiolillo, M., Pansini, M., and Taviani, M.: Role of deep sponge grounds in the Mediterranean Sea: a case study in southern Italy, Hydrobiologia, 687, 163-177, 2012.

Bongiorni, L.: Microbial biodiversity and functional role in benthic food webs of the Condor seamount, in CONDOR Observatory for long-term study and monitoring of Azorean seamount ecosystems, Final Project Report, Arquivos do DOP, Série Estudos 1/2012, Horta, Portugal, 92-99, 2011.

Braga-Henriques, A., Pereira, J. N., Tempera, F., Porteiro, F. M., Pham, C., Morato, T., and Santos, R. S.: Cold-water coral communities on Condor Seamount; initial interpretations, in CONDOR Observatory for long-term study and monitoring of Azorean seamount ecosystems, Final Project Report, Arquivos do DOP, Série Estudos 1/2012, Horta, Portugal, 105-114, 2011.

Buchanan, J. Y.: On oceanic shoals discovered in the S.S. "Dacia" in October, 1883, P. Roy. Soc. Edinb. B, 13, 428-443, 1886.

Carpine-Lancre, J. and Saldanha, L. V. C.: Dom Carlos I, Roi de Portugal, Albert Ier, Prince de Monaco: Souverains Océanographes. Fundação Calouste Gulbenkian, Lisboa, 1992.

Cherkis, N. Z., Steinmetz, S., Schreiber, R., Thiede, J., and Theiner, J.: Vesteris Seamount: An enigma in the Greenland Basin, Mar. Geophys. Res., 16, 287-301, 1994.

Christiansen, B. and Wolff, G.: The oceanography, biogeochemistry and ecology of two NE Atlantic seamounts: The OASIS project, Deep-Sea Res. Pt II., 56, 2579-2581, 2009.

Christiansen, B., Martin, B., and Hirch, S.: The benthopelagic fish fauna on the summit of Seine Seamount, NE Atlantic: Composition, population structure and diets, Deep-Sea Res. Pt. II, 56, 2705-2712, 2009.

Clark, M. R., Rowden, A., Schlacher, T., Williams, A., Consalvey, M., Stocks, K. I., Rogers, A. D., O’Hara, T. D., White, M., Shank, T. M., and Hall-Spencer, J. M.: The Ecology of Seamounts: Structure, Function, and Human Impacts, Ann. Rev. Mar. Sci., 2, 253-278, 2010.

Clark, M. R., Schlacher, T.., Rowden, A. A., Stocks, K. I., and Consalvey, M.: Science Priorities for Seamounts: Research Links to Conservation and Management, PLoS ONE 7, e29232, doi:10.1371/journal.pone.0029232, 2012.

Colaço, A., Raghukumar, C., Mohandass, C., Cardigos, F., and Santos, R. S.: Effect of shallow-water venting in Azores on a few marine biota, Cah. Biol. Mar., 47, 359-364, 2006.

Colaço, A., Giacomello, E., Lambardi, P., Martins, A., Porteiro, F. M., Silva, M., Sousa, A. F., Tempera, F., and Menezes, G.: Trophodynamic studies of the Condor seamount, in CONDOR Observatory for long-term study and monitoring of Azorean seamount ecosystems, Final Project Report, Arquivos do DOP, Série Estudos 1/2012, Horta, Portugal, 191-200, 2011. 
Dekov, V. M. and Savelli, C.: Hydrothermal activity in the SE Tyrrhenian Sea: an overview of 30 years of research, Mar. Geol., 204, 161-185, 2004.

D’Oriano, F., Angeletti, L., Capotondi, L., Laurenzi, M. A., López Correa, M., Taviani, M., Torelli, L., Trua, T., Vigliotti, L., and Zitellini, N.: Coral Patch and Ormonde seamounts as a product of the Madeira hotspot, Eastern Atlantic Ocean, Terra Nova, 22, 494-500, 2010.

Etnoyer, P., Wood, J., and Shirley, T. C.: How large is the seamount biome?, Oceanography, 23, 206-209, 2010.

Ettoumi, B., Bouhajja, E., Borin, S., Daffonchio, D., Boudabous, A., and Cherif, A.: Gammaproteobacteria occurrence and microdiversity in Tyrrhenian Sea sediments as revealed by cultivationdependent and -independent approaches, Syst. Appl. Microbiol., 33, 222-231, 2010.

FAO (Food and Agriculture Organization): International guidelines for the management of deep-sea fisheries in the high seas, Food and Agricultural Organization of the United Nations, Rome, Italy, 2009.

Fock, H., Uiblein, F., Köster, F., and Westernhagen, H. V.: Biodiversity and species-environment relationships of the demersal fish assemblage at the Great Meteor Seamount (subtropical NE Atlantic), sampled by different trawls, Mar. Biol., 141, 185-199, 2002.

Freiwald, A., Beuck, L., Rüggeberg, A., Taviani, M., and Hebbeln, D.: R/V Meteor Cruise M70-1 Participants: The white coral community in the central Mediterranean Sea revealed by ROV surveys, Oceanography, 22, 58-74, 2009.

Gage, J. D.: Deep-sea benthic community and environmental impact assessment at the Atlantic Frontier, Cont. Shelf Res, 21, 957-986, 2001.

Galil, B. and Zibrowius, H.: First benthos samples from Eratosthenes Seamount, Eastern Mediterranean comments on the fauna foraminiferans, Senck. Marit., 28, 111-121, 1998.

Genin, A.: Bio-physical coupling in the formation of zooplankton and fish aggregations over abrupt topographies, J. Mar. Syst., 50, 3-20, 2004.

Genin, A., Dayton, P. K., Lonsdale, P. F., and Spiess, F. N.: Corals on seamount peaks provide evidence of current acceleration over deep-sea topography, Nature, 322, 59-61, 1986.

George, K. H. and Schminke, H. K.: Harpacticoida (Crustacea, Copepoda) of the Great Meteor seamount, with first conclusions as to the origin of the plateau fauna, Mar. Biol., 141, 887-895, 2002.

Giacomello, E. and Menezes, G. (Eds.): CONDOR Observatory for long-term study and monitoring of Azorean seamount ecosystems, Final Project Report, Arquivos do DOP, Série Estudos 1/2012, Horta, Portugal, 2011.

Gofas, S.: Rissoidae (Mollusca: Gastropoda) from northeast Atlantic seamounts, J. Nat. Hist., 41, 779-885, 2007.

Halfar, J. and Fujita, R. M.: Danger of deep-sea mining, Science, 316, 987, 2007.

He, G., Ma, W., Song, C., Yang, S., Zhu, B., Yao, H., Jiang, X., and Cheng, Y.: Distribution characteristics of seamount cobalt-rich ferromanganese crusts and the determination of the size of areas for exploration and exploitation, Acta Oceanol. Sin., 30, 63-75, 2011.

Hein, J., Conrad, T., and Staudigel, H.: Seamount mineral deposits a source of rare metals for high-technology industries, Oceanog- raphy, 23, 184-189, 2010.

Hempel, P., Schreiber, R., Johnson, L., and Thiede, J.: The Vesterisbanken Seamount (Greenland Basin): Patterns of morphology and sediment distribution, Mar. Geol., 96, 175-185, 1991.

Henrich, R., Freiwald, A., Betzler, C., Bader, B., Schäfer, P., Samtleben, C., Brachert, T. C., Wehrmann, A., Zankl, H., and Kühlmann, D. H. H.: Controls on modern carbonate sedimentation on warm-temperate to arctic coasts, shelves and seamounts in the Northern Hemisphere: Implications for fossil counterparts, Facies, 32, 71-108, 1995.

Hesthagen, I. H.: SeamountsOnline: On the near-bottom plankton and benthic invertebrate fauna of the Josephine Seamount and the Great Meteor Seamount, Meteor Forschungsergebnisse, D8, 61-70, 1970.

Hillier, J. K. and Watts, A. B.: Global distribution of seamounts from ship-track bathymetry data, Geophys. Res. Lett., 34, 1-5, 2007.

Howe, J. A., Stoker, M. S., Masson, D. G., Pudsey, C. J., Morris, P., Larter, R. D., and Bulat, J.: Seabed morphology and the bottomcurrent pathways around Rosemary Bank seamount, northern Rockall Trough, North Atlantic, Mar. Petrol. Geol., 23, 165-181, 2006.

Howell, K. L., Davies, J. S., Hughes, D. J., and Narayanaswamy, B. E.: Strategic environmental assessment? special area for conservation photographic analysis report, A report to the Department of Trade and Industry, 163 p., 2007.

Howell, K. L., Davies, J. S., and Narayanaswamy, B. E.: Identifying deep-sea megafaunal epibenthic assemblages for use in habitat mapping and marine protected area network design, J. Mar. Biol. Assoc. UK, 90, 36-68, 2010a.

Howell, K. L., Mowles, S. L., and Foggo, A.: Mounting evidence: near-slope seamounts are faunally indistinct from an adjacent bank, Mar. Ecol., 31, 52-62, 2010b.

Hubbs, C. L.: Initial discoveries of fish fauna on seamounts and offshore banks in the Eastern Pacific, Pac. Sci., 13, 311-316, 1959.

International Hydrographic Organization: Standardization of undersea feature names, http://www.gebco.net/, retrieved 4 May 2011, 2008.

Jacobs, C. L.: An appraisal of the surface geology and sedimentary processes within SEA7, the UK continental shelf, National Oceanography Centre Southampton Research and Consultancy Report, No. 18, 2006.

Jakobsson, M., Macnab, R., Mayer, L., Anderson, R., Edwards, M., Hatzky, J., Schenke, H. W., and Johnson, P.: An improved bathymetric portrayal of the Arctic Ocean: Implications for ocean modeling and geological, geophysical and oceanographic analyses, Geophys Res. Lett., 35, L07602, doi:10.1029/2008GL033520, 2008.

JNCC (Joint Nature Conservation Committee): Offshore Special Area of Conservation: Anton Dohrn Seamount. SAC Selection Assessment Document Version 2 (12th December 2011), 27 p., http://jncc.defra.gov.uk/page-4534\#AntonDohrn, retrieved 1 March 2011, 2012.

Kim, S.-S. and Wessel, P.: New global seamount census from altimetry-derived gravity data, Geophys. J. Int., 186, 615-631, 2011.

Kitchingman, A. and Lai, S.: Inferences on potential seamount locations from mid resolution bathymetric data, in: Seamounts: biodiversity and fisheries, Fisheries Centre Research Reports, 12, 
University of British Columbia, Canada, 7-12, 2004.

Kitchingman, A., Lai, S., Morato, T., and Pauly, D.: How many seamounts are there and where are they located?, in: Seamounts: ecology, fisheries and conservation, Fish and Aquatic Resources Series 12, Blackwell, Oxford, 26-40, 2007.

Koppers, A. A. P. and Watts, A. B.: Intraplate seamounts as a window into deep Earth processes, Oceanography, 23, 42-57, 2010.

Koslow, J. A., Gowlett-Holmes, K., Lowry, J. K., O'Hara, T. D., Poore, G. C. B., and Williams, A.: Seamount benthic macrofauna off southern Tasmania: community structure and impacts of trawling, Mar. Ecol. Prog. Ser., 213, 111-125, 2001.

Lourenço, N., Miranda, J. M., Luís, J. F., Ribeiro, A., Mendes Victor, L. A., Madeira, J., and Needham, H. D.: Morpho-tectonic analysis of the Azores Volcanic Plateau from a new bathymetric compilation of the area, available at: ftp://ftp.ualg.pt/users/jluis/ candi_data/ac_plateau1km.grd, Mar. Geophys. Res., 20, 141156,1998

Madina, M.: Oceana applauds Spanish and Balearic Government support to protect balearic seamounts, http://eu.oceana.org/en/eu/media-reports/press-releases/oceanaapplauds-spanish-and-balearic-government-support-to-protectbalearic-seamounts, 2011.

Martin, B. and Christiansen, B.: Distribution of zooplankton biomass at three seamounts in the NE Atlantic, Deep-Sea Res. Pt. II, 56, 2671-2682, 2009.

Martin, B. and Nellen, W.: Composition and distribution of zooplankton at Great Meteor Seamount, subtropical NE Atlantic, Arch. Fish. Mar. Res., 51, 89-100, 2004.

Mayer, L., Bell, K. L. C., Ballard, R., Nicolaides, S., Konnaris, K., Hall, J., Tibor, G., Austin Jr., J. A., and Shank, T. M.: Discovery of sinkholes and seeps on Eratosthenes Seamount, in: New Frontiers in Ocean Exploration: The E/V Nautilus 2010 field season, Oceanography, 24, 28-29, 2011.

McClain, C. R.: Seamounts: identity crisis or split personality?, J. Biogeogr., 34, 2001-2008, 2007.

Menard, H. W.: Marine Geology of the Pacific, McGraw-Hill, New York, 1964.

Mendonça, A., Arístegui, J., Vilas, J. C., Montero, M. F., Ojeda, A., Espino, M., and Martins, A.: Is There a seamount effect on microbial community structure and biomass? The case study of Seine and Sedlo seamounts (northeast Atlantic), PLoS ONE 7, e29526, doi:10.1371/journal.pone.0029526, 2012.

Menezes, G., Sigler, M., Silva, H., and Pinho, M.: Structure and zonation of demersal fish assemblages off the Azores Archipelago (mid-Atlantic), Mar. Ecol. Prog. Ser., 324, 241-260, 2006.

Menezes, G. M., Rosa, A., Melo, O., and Pinho, M. R.: Demersal fish assemblages off the Seine and Sedlo seamounts (northeast Atlantic), Deep-Sea Res. Pt. II, 56, 2683-2704, 2009.

Menezes, G., Diogo, H., and Giacomello, E.: Commercial fishing for demersal fish, in CONDOR Observatory for long-term study and monitoring of Azorean seamount ecosystems, Final Project Report, Arquivos do DOP, Série Estudos 1/2012, Horta, Portugal, 211-233, 2011.

Monteiro, P., Ribeiro, D., Silva, J. A., Bispo, J., and Gonçalves, J. M. S.: Ichthyofauna assemblages from two unexplored Atlantic seamounts: Northwest Bank and João Valente Bank (Cape Verde archipelago), Sci. Mar., 72, 133-143, 2008.
Morato, T., Cheung, W. W. L., and Pitcher, T. J.: Vulnerability of seamount fish to fishing: fuzzy analysis of life-history attributes, J. Fish Biol., 68, 209-221, 2006.

Morato, T., Machete, M., Kitchingman, A., Tempera, F., Lai, S., Menezes, G., Pitcher, T. J., and Santos, R. S.: Abundance and distribution of seamounts in the Azores, Mar. Ecol. Prog. Ser., 357, 17-21, 2008.

Morato, T., Bulman, C., and Pitcher, T. J.: Modelled effects of primary and secondary production enhancement by seamounts on local fish stocks, Deep-Sea Res. Pt II., 56, 2713-2719, 2009.

Morato, T., Hoyle, S. D., Allain, V., and Nicol, S. J.: Seamounts are hotspots of pelagic biodiversity in the open ocean, P. Natl. Acad. Sci. USA, 107, 9707-9711, 2010a.

Morato, T., Hoyle, S. D., Allain, V., and Nicol, S. J.: Tuna longline fishing around West and Central Pacific seamounts, PloS one, 5, e14453, doi:10.1371/journal.pone.0014453, 2010b.

Morato, T., Pitcher, T. J., Clark, M. R., Menezes, G., Tempera, F., Porteiro, F., Giacomello, E., and Santos, R. S.: Can we protect seamounts for research?, Oceanography, 23, 190-199, 2010c.

Mougenot, D., Kidd, R. B., Mauffret, A., Regnauld, H., Rothwell, R. G., and Vanney, J.-R.: Geological interpretation of combined SEABEAM, GLORIA and seismic data from Porto and Vigo Seamounts, Iberian continental margin, Mar. Geophys. Res., 6, 329-363, 1984.

Mouriño, B., Fernández, E., Serret, P., Harbour, D., and Sinha, B.: Variability and seasonality of physical and biological fields at the Great Meteor Tablemount (subtropical NE Atlantic), Oceanol. Acta, 24, 167-185, 2000.

Narayanaswamy, B. E.: The influence that seamounts have on macrofaunal standing stock and community structure in surrounding deep-sea sediments, WP 3: Seamount Ecosystems, Deliverable 3.4, Final Report for Hotspot Ecosystem Research and Man's Impact on European Seas, 34 p., 2012.

Narayanaswamy, B. E., Howell, K. L., Hughes, D. J., Davies, J. S., and Roberts, J.: Strategic Environmental Assessment Area 7: photographic analysis, A report to the Department of Trade and Industry, p. 179, 2006.

NEAFC (North-East Atlantic Fisheries Commission): 30th Annual Meeting of the North-East Atlantic Fisheries Commission 7 11 November 2011, NEAFC headquarters, London, available at: http://www.neafc.org, 2011.

Nellen, W. and Ruseler, S.: Composition, horizontal and vertical distribution of ichthyoplankton in the Great Meteor Seamount area in September 1998, Arch. Fish. Mar. Res., 51, 132-164, 2004.

OCEANA: Propuesta de Áreas Marinas de Importancia Ecológica. Atlántico sur y Mediterráneo español, OCEANA, Madrid, Spain, 2008.

OCEANA: Seamounts of the Balearic Islands. Proposal for a Marine Protected Area in the Mallorca Channel, OCEANA, Madrid, Spain, 2010.

O'Hara, T. D.: Seamounts: centres of endemism or species richness for ophiuroids?, Global Ecol. Biogeogr., 16, 720-732, 2007.

OSPAR: Descriptions of habitats on the OSPAR list of threatened and/or declining species and habitats. OSPAR Convention for the Protection of the Marine Environment of the North-East Atlantic, Reference Number 2008-07, available at: http://www.ospar.org/documents/DBASE/DECRECS/ Agreements/08-07e_Priority20habitat20definitions.doc), 2008. 
Pakhorukov, N. P.: Visual observations of fish from seamounts of the Southern Azores region (the Atlantic Ocean), J. Ichthyol., 48, 114-123, 2008.

Perrone, A.: Report on the biological survey of Amendolara Seamount: Nudibranchia of Amendolara Seamount, J. Mollus. Stud., 51, 102-103, 1982.

Piepenburg, D. and Müller, B.: Distribution of epibenthic communities on the Great Meteor Seamount (NE Atlantic) mirrors water column processes, ICES CM:2002/M:13, 2002.

Pitcher, T. J.: Eight major target species in world seamount fisheries, Oceanography, 23, 130-131, 2010.

Pitcher, T. J., Morato, T., Stocks, K. I., and Clark, M. R.: Seamount Ecosystem Evaluation Framework (SEEF): a tool for global seamount research and data synthesis, Oceanography, 23, 123$125,2010$.

Pitcher, T. J., Morato, T., Haggan, N., Hart, P. J. B., Clark, M. R., and Santos, R. S. (Eds.): Seamounts: Ecology, Fisheries and Conservation, Blackwell, Oxford, UK, 2007.

Pitcher, T. J., Clark, M. R., Morato, T., and Watson, R.: Seamount fisheries: Do they have a future?, Oceanography, 23, 134-144, 2010.

Porteiro, F. M.: A importância das campanhas oceanográficas do Príncipe Albert I do Mónaco para o conhecimento do Mar dos Açores, Boletim do Núcleo Cultural da Horta, available at: http://www.nch.pt/biblioteca-virtual/bol-nch18/Boletim_ 2009-p179.pdf, 18, 189-219, 2009.

Richer de Forges, B., Grandperrin, R., and Laboute, P.: La campagne CHALCAL II sur les guyots de la ride de Norfolk. N.O. "CORIOLIS" 26 Octobre-1 Novembre 1986, Institut Français de Recherche Scientifique pour le Developpement en Cooperacion, Noumea, New Caledonia, 1987.

Robertson, A.: Tectonic significance of the Eratosthenes Seamount: a continental fragment in the process of collision with a subduction zone in the eastern Mediterranean (Ocean Drilling Program Leg 160), Tectonophysics, 298, 63-82, 1998.

Roden, G. I.: Effect of seamounts and seamount chains on ocean circulation and thermohaline structure, in: Seamounts, Islands and Atolls, Am. Geophys. Union, Geophys. Monogr. Ser., 43, 335354, 1987.

Rogers, A. D.: The biology of seamounts, Adv. Mar. Biol., 30, 305350, 1994.

Rowden, A. A, Clark, M. R., and Wright, I. C.: Physical characterisation and a biologically focused classification of seamounts in the New Zealand region, New Zeal. J. Mar. Fresh., 39, 10391059, 2005.

Samadi, S., Bottan, L., Macpherson, E., Forges, B. R., and Boisselier, M.-C.: Seamount endemism questioned by the geographic distribution and population genetic structure of marine invertebrates, Mar. Biol., 149, 1463-1475, 2006.

Santos, R. S., Christiansen, S., Christiansen, B., and Gubbay, S.: Toward the conservation and management of Sedlo Seamount: A case study, Deep-Sea Res. Pt. II, 56, 2720-2730, 2009.

Santos, R. S., Tempera, F., Menezes, G., Porteiro, F., and Morato, T.: Spotlight 12: Sedlo Seamount, Oceanography, 23, 202-203, 2010.

Schnack-Schiel, S. B. and Henning, S.: Occurrence and distribution pattern of mesozooplankton in the vicinity of the Great Meteor Seamount (subtropical North-east Atlantic), Arch. Fish. Mar. Res., 51, 101-114, 2004.
Sevastou, K., Lampadariou, N., Kalogeropoulou, V., Polymenakou, P., and Tselepides, A.: Meiobenthic communities at Eratosthenes Seamount: preliminary results, HERMIONE 1st Annual Meeting, Estepona, Spain, 11-15 April 2011.

Shank, T. M.: Seamounts: deep-ocean laboratories of faunal connectivity, evolution, and endemism, Oceanography, 23, 108-122, 2010.

Shank, T. M., Herrera, S., Cho, W., Roman, C. N., and Bell, K. L. C.: Exploration of the Anaximander Mud Volcanoes, in: New Frontiers in Ocean Exploration: The E/V Nautilus 2010 field season, Oceanography, 24, 22-23, 2011.

Staudigel, H. and Clague, D. A.: The geological history of deep-sea volcanoes: Biosphere, hydrosphere, and lithosphere interactions, Oceanography, 23, 58-71, 2010.

Staudigel, H., Koppers, A. A. P., Lavelle, J. W., Pitcher, T. J., and Shank, T. M.: Defining the Word "Seamount", Oceanography, 23, 20-21, 2010.

Stewart, H., Davies, J., Long, D., Strömberg, H, and Hitchen, K.: JNCC Offshore Natura Survey. Anton Dohrn Seamount and East Rockall Bank areas of search, 2009/03-JNCC Cruise Report No. CR/09/113, 90 p., 2009.

Stocks, K. I., Clark, M. R., Rowden, A. A., Consalvey, M., and Schlacher, T.: CenSeam, an International Program on Seamounts within the Census of Marine Life: Achievements and Lessons Learned, PLoS ONE, 7, e32031, doi:10.1371/journal.pone.0032031, 2012.

Strusi, A., Tursi, A., Cecere, E., Montanaro, C., Panetta, P., and Cavallo, R.: The Amendolara Seamount (High Ionian Sea): General Description, Oebalia, 11, 379-388, 1985.

Tanner, S. J. and Williams, C.: A detailed survey near Mount Eratosthenes Eastern Mediterranean, Mar. Geophys. Res., 6, 205-222, 1984.

Taranto, G. H., Kvile, K. Ø., Pitcher, T. J., and Morato, T.: An ecosystem evaluation framework for global seamount conservation and management, PLoS ONE, 7, e42950, doi:10.1371/journal.pone.0042950, 2012.

Tempera, F., Giacomello, E., Mitchell, N., Campos, A. S., BragaHenriques, A., Martins, A., Bashmachnikov, I., Morato, T., Colaço, A., Porteiro, F. M., Catarino, D., Gonçalves, J., Pinho, M. R., Isidro, E. J., Santos, R. S., and Menezes, G.: Mapping the Condor seamount seafloor environment and associated biological assemblages (Azores, NE Atlantic), in: Seafloor Geomorphology as Benthic Habitat: Geohab Atlas of Seafloor Geomorphic Features and Benthic Habitats, Elsevier, London, 807-818, 2012.

Trua, T., Serri, G., Marani, M., Renzulli, A., and Gamberi, F.: Volcanological and petrological evolution of Marsili Seamount (southern Tyrrhenian Sea), J. Volcanol. Geoth. Res., 114, 441464, 2002.

Uiblein, F., Geldmacher, A., Koester, F., Nellen, W., and Kraus, G.: Species composition and depth distribution of fish species collected in the area of the Great Meteor seamount, Eastern Central Atlantic, during cruise M42/3 with seventeen new records, Informes Tecnicos del Instituto Canario de Ciencas Marinas, 5, 49-85, 1999.

Van Dover, C. L.: Tighten regulations on deep-sea mining, Nature, 470, 31-33, 2011.

Varnavas, S., Papaioannou, J., and Catani, J.: A hydrothermal manganese deposit from the Eratosthenes Seamount, Eastern Mediterranean Sea, Mar. Geol., 81, 205-214, 1988. 
Vastano, A. C., Hagen, D. E., and McNally, G. J.: Lagrangian observations of surface circulation at the Emperor seamount chain, J. Geophys. Res., 90, 3325-3331, 1985.

Vilas, J. C., Arístegui, J., Kiriakoulakis, K., Wolff, G. A., Espino, M., Polo, I., Montero, M. F., and Mendonça, A.: Seamounts and organic matter - Is there an effect? The case of Sedlo and Seine Seamounts: Part 1. Distributions of dissolved and particulate organic matter, Deep-Sea Res. Pt II, 56, 2618-2630, 2009.

von Stackelberg, U., von Rad, U., and Zobel, B.: Asymmetric sedimentation around Great Meteor Seamount (North Atlantic), Mar. Geol., 33, 117-132, 1979.

Watts, A. B., Cochran, J. R., and Selze, G.: Gravity anomalies and flexure of the lithosphere: A three-dimensional study of the Great Meteor Seamount, J. Geophys. Res., 80, 1391-1398, 1975.

Wendt, I., Kreuzer, H., Müller, P., Rad, U. V., and Raschka, H.: K-Ar age of basalts from Great Meteor and Josephine seamounts (eastern North Atlantic), Deep-Sea Res. Pt. II, 23, 849-862, 1976.

Wessel, P.: Seamount characteristic, in: Seamounts: ecology, fisheries and conservation, Fish and Aquatic Resources Series 12, Blackwell, Oxford, 3-25, 2007.

Wessel, P., Sandwell, D. T., and Kim, S. S.: The global seamount census, Oceanography, 23, 24-33, 2010.
Wienberg, C., Wintersteller, P., Beuck, L., and Hebbeln, D.: Coral Patch seamount (NE Atlantic) - a sedimentological and macrofaunal reconnaissance based on video and hydroacoustic surveys, Biogeosciences Discuss., 9, 18707-18753, doi:10.5194/bgd-918707-2012, 2012.

White, M., Bashmachnikov, I., Arístegui, J., and Martins, A.: Physical processes and seamount productivity, in: Seamounts: ecology, fisheries and conservation, Fish and Aquatic Resources Series 12, Blackwell, Oxford, 65-84, 2007.

Williams, A., Schlacher, T. A., Rowden, A. A., Althaus, F., Clark, M. R., Bowden, D. A., Stewart R., Bax, N. J., Consalvey, M., and Kloser, R. J.: Seamount megabenthic assemblages fail to recover from trawling impacts, Mar. Ecol., 31, 183-199, 2010.

Yesson, C., Clark, M. R., Taylor, M. L., and Rogers, A. D.: The global distribution of seamounts based on 30-second bathymetry data, Deep-Sea Res. Pt I, 58, 442-453, 2011.

Zitellini, N., Gràcia, E., Matias, L., Terrinha, P., Abreu, M. A., DeAlteriis, G., Henriet, J. P., Dañobeitia, J. J., Masson, D. G., Mulder, T., Ramella, R., Somoza, L., and Diez, S.: The quest for the Africa-Eurasia plate boundary west of the Strait of Gibraltar, Earth Planet. Sci. Lett., 280, 13-50, 2009. 